\title{
Perception of Recommendation Label on Consumer Purchasing Decisions at Padang Restaurant
}

\author{
Afifah $^{1}$, Tuti Azra ${ }^{2}$, Alhapen R.C. ${ }^{3}$, Emrizal $^{4}$, Anggun Dwi Utami ${ }^{5}$ \\ \{afifah@pnp.ac.id ${ }^{1}$,tuti fathan@yahoo.com², alhapen.chandra@gmail.com³ \\ emrizal_se@yahoo.com ${ }^{4}$, anggun.du@gmail.com ${ }^{5}$ \} \\ Politeknik Negeri Padang, Kampus Limau Manis Padang 1,2,3,4,5
}

\begin{abstract}
The Padang government has made a policy in the form of providing Recommendation Labels to Padang restaurants that have met the required criteria. This labeling aims to provide comfort and security to consumers who use services at Padang Restaurant. The research carried out in this paper aims to determine consumer perceptions of the Recommendation Label and the influence of the Recommendation Label perception on consumer purchasing decisions at Padang Restaurant. A total of 100 respondents who were taken by incidental sampling were included in this study. Data obtained from respondents were analyzed using the simple linear regression method. As a result, consumers positively perceive the Recommendation Label but do not make the main basis in making purchasing decisions. Perceived Label Recommendation has a positive and significant effect of 66.4 percent on consumer purchasing decisions at Padang Restaurant
\end{abstract}

Keywords: Recommendation label, Purchase decision, Padang restaurant

\section{INTRODUCTION}

One of the factors supporting the Indonesian's economic growth is the development of the food industry. The development of this industry has an impact on the growth of businesses in the culinary field. Data from the Republic of Indonesia's Creative Economy Agency (Bekraf) noted that the culinary subsector contributed 41.69 percent of the total creative economy contribution. This level is the highest compared to 16 other subsectors posted on the Bekraf RI website, [1]. The development of the culinary business also spread to the West Sumatra region marked by the emergence of restaurants and cafes that serve local, national and international food products. Even so, local food products, better known as Masakan Padang, still have a special attraction for tourists. Masakan Padang are for sale at Rumah Makan Padang and several restaurants in the city of Padang. Data from the Central Statistics Agency in 2016 noted that the number of restaurants in the city of Padang was 254 restaurants, [2]. Based on these figures, it can be concluded that there is intense competition between business people. This intense competition requires business people to be able to maximize the performance of their restaurants in order to win the competition. Performance maximization can be done including by: paying attention to product quality, product prices, improving the services, increasing accuracy of the use of promotional media which ultimately becomes the basis for consumers in making choices before making a purchase. In this regard, the Padang City Government appreciates the Rumah Makan Padang restaurant which has met government standards by providing a Recommendation Label installed in front of its restaurant. The results of an interview with the Padang City Tourism Office, recommendation labeling have been carried out since 2016, it has been recorded that until 2019, 56 Rumah Makan Padang restaurant have received a recommendation label The function of this label is to help promote the restaurant itself and support the development of tourism in the City of Padang. Another function is to provide guarantees to consumers that this restaurant meets the basic standards of a restaurant and there is 
already clarity about prices and products. Therefore it is necessary to know how consumers' perceptions of the existence of the recommendation label and its effect on purchasing decisions at the Padang Restaurant Labeled Recommendations (Rumah Makan Padang Berlabel Rekomendasi, RMPBR).

Perception itself is a process used by individuals to select, organize, and translate input information to create a meaningful picture of the world, [3]. In line with the opinion of [4] that perception is an impression obtained by individuals through the five senses then analyzed (organized), interpreted, so that the individual obtains meaning. [5] defines perception is the process by which a person chooses, organizes, and interprets information received from the environment. From the definitions of these experts, it can be concluded that perception is a view, image or response of someone about something. [6] states perception is the process by which individuals are exposed to receive information, pay attention and understand it. Perception does not arise just like that, before becoming a perception that can affect consumer psychology, information received by consumers must get the attention, understanding, and memories of consumers. Perception is a part of consumer psychology,[3]. The psychological factors that influence an individual's decision to make a purchase are further categorized into the individual's motivations, perceptions, learning and his beliefs and attitudes [7]. The entire researchers agreed that motivation, perception and attitude positively and significantly influence consumer purchasing decision [8], [9].

[10] defines purchase decision is a process carried out to combine the knowledge obtained to evaluate two or more alternatives so that they can decide on one product. [3] revealed that before consumers decide to buy, consumers go through several stages, starting from problem recognition, information search, alternative evaluation, purchasing decisions, and at the end of the stage, there are post-purchase behaviors. [3] also said to produce a decision, it is beginning with the stimulus response that enters consumer awareness. The same opinion is also conveyed by [11] who describe the central component of the consumer behavior model is consumer decision making which is influenced by three main factors namely: consumer psychology, the influence of the environment and marketing stimuli and other stimuli that mediate consumer interest in making decisions about the products offered. Furthermore, the consumer purchasing decisions are defined as the decisions made about purchasing either products or services from a pet retailer [12].

[11] is applied in a study that aims to determine the perception of halal labels on consumer purchasing decisions on energy drink products. The results of the study explained that there is a significant influence between the perceptions of halal labels on purchasing decisions. This means that consumers make a decision to purchase energy drinks that are inseparable from the perception process. Indicators to measure consumer perceptions of labels are: attention, understanding and memory. These indicators are also used in this study. [13] also conducted research related to purchasing decisions: looking at the effect of perceptions of halal labels and product quality on purchasing decisions for Muslim fashion products (survey of Zoya product on muslim customers in Malang). The results of the study found that the perception of halal labels significantly influence purchasing decisions. It can be concluded that the halal label on Zoya creates a good perception so consumers decide to buy Zoya products. Other research related to purchasing decisions was also conducted by [14]. This research aims to determine the relationship between brand dimensions and Jordanian consumer purchasing decisions. The dimensions of the brand itself include: loyalty, quality, marketing communications, historical traditions, and country of origin. The result: loyalty, marketing communication, and country of origin have a significant relationship to purchasing decisions, while the quality and historical tradition has no effect. Indicators to measure Jordanian consumer purchasing decisions include: problem recognition, information search, alternative evaluations, purchasing decisions, and post-purchase behavior. This indicator is also used to measure purchasing decisions of Padang restaurant consumers labeled with recommendations.

\section{RESEARCH METHOD}

This research was conducted at RMPBR with the object of research being consumers who were visiting and making purchases at the restaurant. The number of consumers is unknown, so the determination of the number of samples is calculated based on the formula used by [15] the number of samples taken is 5 
to 10 times the number of indicators to be studied. This study uses 10 times the number of indicators used with the following calculations:

$$
\begin{aligned}
\mathrm{n} & =\{5-10 \text { times the number of indicators }\} \\
& =10 \times 8 \text { indicators } \\
& =80 \text { people }
\end{aligned}
$$

To obtain a better result, the number of respondents used in this research is 100 people. The sampling technique uses the incidental sampling method which is a technique of determining samples based on coincidence, that is, any consumer who makes a purchase accidentally meets at the research location with the researcher can be used as a sample, if it is considered a person who happens to be suitable as a source of data [16]

Data from respondents were collected through questionnaires. Questionnaires are made in the form of questions to determine the behavior of consumer visits and also made in the form of statements to determine the perception of label recommendations and purchasing decisions. The questionnaire requires answers in the form of a multilevel scale that has gradations from very positive to negative or better known as the Likert scale. In this study a 5 point Likert scale from: Strongly Agree was given a score of 5 (five) to Very Disagree was given a score of 1 (one).

The research data obtained were further processed using the SPSS version 16.0 and analyzed using simple linear regression. Hertanto in his writings on the academia.edu site said, a simple linear regression analysis is an analysis that is used to look for an effect on an independent variable with one dependent variable. Data analysis conducted in this study has a general equation formed from simple linear regression analysis, see equation (1)

where:

$$
\mathbf{Y}=\mathbf{a}+\mathbf{b X}
$$

$$
\begin{aligned}
& \mathrm{Y}=\text { dependent variable } \\
& \mathrm{a}=\text { constant } \\
& \mathrm{b}=\text { coefficient of independent variable } \\
& \mathrm{X}=\text { independent variable }
\end{aligned}
$$

This simple linear regression analysis is used to determine the effect of variable $\mathrm{X}$ (Recommended Label Perception) on variable Y (Purchase Decision). Variable X is measured through indicators: attention to labels, understanding of labels and consumers' memories of labels. The $\mathrm{Y}$ variable is measured by indicators: problem recognition, information search, alternative evaluations, purchasing decisions, and postpurchase behavior. The percentage change in variable $\mathrm{Y}$ due to variable $\mathrm{X}$ is explained by the value of the coefficient reflected or $\mathrm{R}^{2}$. [17] said that if $\mathrm{R}^{2}$ gets bigger, then the percentage change in the dependent variable (Y) caused by the independent variable $(\mathrm{X})$ is higher. Conversely, if $\mathrm{R}^{2}$ gets smaller, the percentage change in the dependent variable $(\mathrm{Y})$ caused by the independent variable $(\mathrm{X})$ is getting lower.

\section{RESULT AND DISCUSSION}

From the results of the study, it was noted some consumer behaviors in visiting the RMPBR, they are: First, consumers visit at least more than 2 times a month. Secondly, these consumer visits are carried out most often during the day especially at lunch hour. Third, visits are carried out with friends, coworkers or business partners usually during the day while many consumer and family visits are conducted at night. In general it can be concluded that consumer visits to RMPBL are always carried out together, it is very rare for consumers to visit alone. Fourth, the main purpose of visiting customers is to enjoy food, very few consumers visit with the main purpose being to relax or talk business. This has become an initial signal that the RMPBR must pay attention to the quality of food products, tastes and services that will be provided to consumers. 


\subsection{Consumer perception of recommendation labels and purchasing decisions}

This study also produced information about consumers' perceptions of the recommendation label given selectively at Padang Restaurant, information that shows the amount of attention, understanding of the purpose of the label and remembrance of the label recommendations. Other information obtained from research activities is information about consumer purchasing decisions to buy at the RMPBR. Information about consumers' perceptions and purchasing decisions in the RMPBR can be seen in Table 1 .

Table 1 shows the respondents' positive opinions on the variable perception of the label recommendations and purchasing decisions in the RMPBR. The mean percentage score of all aspects of the perception variable measurement shows that: a) the aspect of attention gets an average score of 48 percent, the aspect of understanding gets an average score of 68 percent and the memory aspect gets an average score of 55 percent; $b$ ) the average aspect score of attention is less than 50 percent. The lack of consumer perception value from the aspect of attention is caused by consumers not making the recommendation label the focus of attention anymore and not seeing the label in detail. This behavior occurs because the customer's visit to the RMPBR is not the first but a repeat visit. Nevertheless consumers understand the meaning of the label and remember it, this is enough to prove that consumers have a positive perception of the Recommendation Label given by the Government of Padang City to Padang Restaurant.

Regarding food purchase decisions at Padang Restaurant, it is generally seen that the recommendation label is not the main basis for decision makers. This can be seen from the process of identifying the needs of no more than 50 percent of consumers who feel the need to buy RMPBR food and is confirmed by the results of only 47 percent of consumers who make the recommendation label as the basis for making decisions. Product prices are still an important element in making purchasing decisions. A significant finding is that dominant consumers who have made food purchase decisions at RMPBR are satisfied with their decisions and make references to make their next purchase decision. This finding supports the results that consumers who visit RMPBR are generally consumers who make repeat purchases.

Table 1. Perceptions of labels and purchasing decisions

\begin{tabular}{|c|c|c|}
\hline Variables & Measurement Aspect & Result (\%) \\
\hline $\begin{array}{l}\text { Consumer perception } \\
\text { against the } \\
\text { Recommendation Label }\end{array}$ & $\begin{array}{l}\text { Attention } \\
\text { - Frequency of frequency of seeing Recommended Labels } \\
\text { - Label recommendations are the center of attention } \\
\text { - Detailed attention } \\
\text { Understanding } \\
\text { - Understanding the purpose of the label } \\
\text { - Labels indicate compliance with Regional Government } \\
\text { - standards } \\
\text { - Understanding the label indicates guaranteed } \\
\text { Memory } \\
\text { - Label form } \\
\text { - The word "Recommended" } \\
\text { Recommended restaurant name }\end{array}$ & $\begin{array}{l}65 \\
68 \\
72\end{array}$ \\
\hline $\begin{array}{l}\text { The purchasing } \\
\text { decision for the Padang } \\
\text { Restaurant } \\
\text { is labeled a } \\
\text { recommendation }\end{array}$ & $\begin{array}{l}\text { - The need to buy food at the RMPBR } \\
\text { - Attention to restaurants labeled with recommendations } \\
\text { - Label recommendations are the center of attention } \\
\text { - Do not prioritize price as long as it has a recommendation } \\
\text { label } \\
\text { - The recommendation label is the basis for making a } \\
\text { purchase decision } \\
\text { - Decide on a purchase at Padang Restaurant labeled a } \\
\text { recommendation } \\
\text { - Satisfied with the decision made } \\
\text { - As a reference for subsequent purchase decisions }\end{array}$ & $\begin{array}{l}46 \\
50 \\
54 \\
44 \\
47 \\
48 \\
64 \\
61\end{array}$ \\
\hline
\end{tabular}




\subsection{Influence of label recommendation perception on purchasing decisions}

Other results of this study are to determine the effect of consumer perceptions on label recommendations and consumer decisions to make purchases. These results are obtained by analyzing the data with a simple linear regression method as shown in Table 2.

Table 2 Regression variable label recommendations and purchasing decisions

\begin{tabular}{|c|c|c|c|c|c|}
\hline \multirow[t]{2}{*}{ Model } & \multicolumn{2}{|c|}{$\begin{array}{c}\text { Unstandardized } \\
\text { Coefficients }\end{array}$} & \multirow{2}{*}{$\begin{array}{r}\begin{array}{l}\text { Standardized } \\
\text { Coefficients }\end{array} \\
\text { Beta }\end{array}$} & \multirow[t]{2}{*}{$\mathbf{T}$} & \multirow[t]{2}{*}{ Sig. } \\
\hline & B & Std. Error & & & \\
\hline (Constant) & 2.756 & 1.832 & & 1.504 & 0.136 \\
\hline $\begin{array}{l}\text { Label Recommendation } \\
\text { (X) }\end{array}$ & 0.770 & 0.055 & 0.815 & 13.923 & 0.000 \\
\hline
\end{tabular}

Based on the Table 2, the resulting equation model is:

$\mathrm{Y}=2.756+0.770 \mathrm{X}$

This regression equation can be interpreted as follows: 1) the constant value (a) of 2.756 means that if the perception of the Recommendation Label $(x)$ is equal to zero (no change) then the consumer purchasing decision (y) on the RMPBR is 2.756. If perceptions of the Recommendation Label increase, consumer purchasing decisions in the RMPBR also increase. 2) Recommendation Label coefficient value (b) of 0.770 means that the Recommendation Label perception variable has a positive and significant influence on consumer purchasing decisions on the RMPBR. The positive effect is due to the significant $b$ value of 0,000 which is small than 0.005 .

To find out the percentage of changes in purchasing decisions (y) caused by the perception of the Recommendation Label (x), it can be seen in the coefficient of determination (R2) in Table 3. The magnitude of the coefficient of determination ( $\mathrm{R}$ square) of 0.664 means that: the influence of the perception variable Recommendation Label of consumer purchase decision variables in the RMPBR is 66.4 percent. While the remaining 33.6 percent is influenced by other variables not yet examined in this study

Table 3. The coefficient of determination of the label recommendations perception of the purchase decision

\begin{tabular}{ccccc}
\hline Model & R & R Square & $\begin{array}{l}\text { Adjusted R } \\
\text { Square }\end{array}$ & $\begin{array}{c}\text { Std. Error of the } \\
\text { Estimate }\end{array}$ \\
\hline 1 & $0.815^{\text {a }}$ & 0.664 & 0.661 & 3.527
\end{tabular}

a. Predictors: (Constant), Label Recommendation

\section{CONCLUSION}

Consumers positively perceive the Recommendation Label given by the City of Padang to Padang Restaurant. Consumers in making food purchase decisions at Padang Restaurants do not make recommendation labels the primary basis for decision makers. Perception of the Recommendation Label has a positive and significant influence on consumer purchasing decisions on the RMPBR. The influence of the perception of the Recommendation Label on consumer purchasing decisions by 66.4 percent while the remaining 33.6 percent is influenced by other variables not examined in this study. Other variables that are 
thought to influence are: marketing mix factors such as product (taste, choice of side dishes), price, place, promotion; restaurant atmosphere; consumer characteristics and consumer psychology. These allegations need to be proven by conducting research activities with the right methodology.

\section{REFERENCES}

[1] B. E. K. Indonesia, "Data Statistik dan Hasil Suvei Ekonomi Kreatif," 2017. [Online]. Available: www.bekraf.go.id. [Accessed: 24-Jul-2019].

[2] Badan Pusat Statistik, "Jumlah Restoran/Rumah Makan Menurut Kecamatan di Kota Padang," 2017. .

[3] P. dan K. L. K. Kotler, Manajemen Pemasaran Edisi 13 Jilid 1, 13th ed. Jakarta: E, 2009.

[4] S. P. Robbins, Perilaku Organisasi Alih. Jakarta: Index, 2001.

[5] J. N. Seth, Robbins, Stephen P. The Dryden Press Harcourt Brace Collage Publishers, 1999.

[6] Sunarto, Perilaku Konsumen,. Yogyakarta: AMUS, 2003.

[7] J. Oluwoye, D. Chembezi, and B. Herbert, "Consumer perception of organic food products and purchase behavior of shopping in outlets of retail chains: A pilot study of Huntsville, Alabama," Int. J. Agric. Res. Sustain. Food Suffic., vol. 4, no. 3, pp. 165-173, 2017.

[8] S. L. Chuah and C. C. Gan, "SSRN-id3000765," Bus. Soc. Sci. Rev., vol. 1, no. 1, pp. 59-69, 2013.

[9] S. Gunawan, "The Impact of Motivation, Perception and Attitude toward Consumer Purchasing Decision: A Study Case of Surabaya and Jakarta Society on Carl's Junior," iBuss Manag., vol. 3, no. 2, pp. 154-163, 2015.

[10] P. \& Olson, Perilaku Konsumen dan Strategi Pemasaran. Jakarta: Salemba Empat, 2013.

[11] A. S. P. Sandi, Marsudi, and D. Rahmawanto, "Persepsi Label Halal Terhadap Keputusan Pembelian Konsumen Pada Produk Minuman Berenergi," J. Manaj. Bisnis, vol. 1, no. 2, pp. 135-143, 2011.

[12] T. Chaipradermsak, "the Infuential Factors on Consumers' Purchasing Decision in Bangkok Pet Retailing Business," p. pp.1-66, 2007.

[13] S. A. Alim, M. K. Mawardi, and A. S. Bafadhal, "Pengaruh Persepsi Label Halal dan Kualitas Produk Terhadap Keputusan Pembelian Produk Fesyen Muslim ( Survei pada Pelanggan Produk Zoya Muslim di Kota Malang )," J. Adm. Bisnis, vol. 62, no. 1, pp. 127-134, 2018.

[14] D. R. A. Momani, "The Impact of Brand Dimension on the Purchasing Decision Making of the Jordanian Consumer for Shopping Goods," Int. J. Bus. Soc. Sci., vol. 6, no. 7, pp. 149-168, 2015.

[15] F. Augusty, Metode Penelitian Manajemen: Pedoman Penelitian untuk skripsi, Tesis dan Disertai Ilmu Manajemen. Semarang: Universitas Diponegoro.

[16] Sugiyono, Metode Penelitian Kualitatif Kuantitatif dan R\&D. Bandung. Bandung: Alfabeta, 2014.

[17] Sujarweni, Metodologi Penelitian Bisnis \& Ekonomi. Yogyakarta: Pustaka Baru Press, 2015. 